\title{
Os governos não centrais: compartilhamento de competências na dimensão subnacional dos estados
}

Idir Canzi*

Marcelo Markus Teixeira**

\section{INTRODUÇÃO}

Importante destacar de que a ordenação político-jurídica dos Estados Nacionais fortaleceu centralmente o Estado como sujeito de direito e, consequentemente, as organizações internacionais constituídas por estes. Entretanto, as transformações processadas ao longo do século XX, entre estas as Conferências de Paz de Haia, a experiência das duas guerras mundiais, a Liga das Nações e a criação da ONU, as Conferências de Viena, a guerra fria e a dinâmica imposta pela globalização econômica influíram decisivamente para fazer ressurgir o debate sobre os sujeitos emergentes da sociedade internacional contemporânea, incluindo aqueles situados na dimensão subnacional e local - governos não centrais (Estados, municípios e comunidades territoriais não estatais).

No que tange ao avanço no debate sobre a natureza e alcance de direito das coletividades públicas territoriais, destaca-se que a partir de 1974 houve disseminação da expressão Comunidades Territoriais, notadamente ante a adoção pelo Conselho da Europa no trato sobre a cooperação das coletividades locais nas regiões de fronteira e instrumentos jurídicos apropriados.

No referido contexto surgiu a Convenção-quadro Europeia sobre a cooperação transfronteiriça entre as coletividades ou autoridades territoriais,

\footnotetext{
* Doutor em Direito Internacional Público pela Universidade Federal de Santa Catarina. Professor Permanente do Programa de Pós-Graduação Stricto Sensu em Direito da UNOCHAPECÓ-SC. Advogado. E-mail: canzi@unochapeco.edu.br.

** Doutor em Direito Internacional Privado pela Universität zu Köln (Alemanha). Professor Permanente do Programa de Pós-Graduação Stricto Sensu em Direito da UNOCHAPECÓ-SC. Advogado e Árbitro. E-mail: marcelomarkus@unochapeco.edu.br.
} 
aberta à assinatura dos Estados-membros do Conselho de Europa em 15 de maio de 1980 (BRITO,2000).

Em 2001, na realização da Jornada de estudos organizada pela Sociedade Francesa para o Direito Internacional, foram apresentados os principais delineamentos tomados pela expressão Comunidades Territoriais ao adentrar no mundo do direito internacional, fornecidos por Emmanuel Jos no âmbito do "Rapport Introductif" do evento:

Trata-se de coletividades no sentido em que elas dispõem de uma personalidade jurídica própria. A existência desta personalidade jurídica de direito interno não levanta nenhuma discussão. Ao contrário, se põe a questão de saber se elas dispõem ou se elas disporão um dia, tanto quanto pareça necessário, da personalidade jurídica internacional. Trata-se de coletividades públicas. Elas são encarregadas da gestão de interesses coletivos e são regidas, geralmente, pelo direito público. São administradas, muito frequentemente, por indivíduos eleitos pelo povo e dispõem, assim, de um grau de legitimidade importante. Trata-se de coletividades públicas territoriais. Elas se distinguem dos estabelecimentos públicos que não têm competências relativas a um espaço territorial circunscrito. As delimitações advêm tanto da geografia, como da história. Elas levam em consideração a economia, a cultura e a vontade pública $^{1}$ (g. a).

O debate central do evento foi permeado pela discussão da natureza e alcance de direitos das coletividades públicas territoriais. Da citação anterior resta explícito o reconhecimento da personalidade jurídica própria das coletividades públicas territoriais que levam em consideração a economia, a cultura e a vontade pública. Entretanto, apesar de restar evidenciado no evento a necessidade de atribuição da personalidade jurídica internacional às referidas coletividades públicas territoriais, tal condição não possui amparo no direito internacional público de base predominantemente estatal.

Em 03 de junho de 2016, o Congresso "Les Villes et le Droit Internacional", realizado na Université Paris Naterre, colocou novamente no centro do debate a importância das cidades e do direito internacional no atual contexto global, aprofundando a discussão sobre a necessária inclusão dos sujeitos de fato situados na dimensão subnacional e local - governos não centrais (Estados, municípios e comunidades territoriais não estatais) nas agendas internacionais e de deliberações sobre economia, cultura e outras políticas públicas (LES VILLES, 2016).

O princípio da exclusividade dos Estados em manter relações com Estados estrangeiros e participar das organizações internacionais apresenta exceções cada vez mais numerosas à medida que empresas públicas nacionais, bancos centrais, universidades, coletividades descentralizadas (Estados Federados 
e Municípios) passam a manter relações internacionais e celebrar convenções e acordos internacionais. Referida atuação no cenário internacional, mesmo com competências muito especializadas e limitadas, geram, atualmente, problemáticas jurídicas em torno da condição de sujeitos possíveis do direito internacional (CARREAU; BICHARA, p. 27).

Os avanços no debate sobre a natureza e alcance de direitos das chamadas coletividades públicas territoriais na Europa e o anunciado Congresso de cidades realizado em Paris, indicam o repensar dos sujeitos de direito internacional e do próprio DIP, para reger as novas demandas na atualidade, com a inclusão obrigatória de novas competências compartilhadas pelos governos não centrais na dimensão subnacional dos Estados.

\section{OS GOVERNOS NÃO CENTRAIS}

Na travessia do século XX foram processadas significativas mudanças no cenário internacional de modo que o Estado deixou de ser o único sujeito de direito internacional. O século XX foi determinante para o surgimento de novos sujeitos do direito internacional capazes de influir na formação tanto das relações quanto do direito internacional, a exemplo das organizações internacionais, das sociedades de empresas transnacionais e das organizações internacionais não estatais. Além desses sujeitos, as últimas décadas do século XX, com o fluxo e influxo do processo de globalização e mudança nos pilares do direito internacional, fez emergir novos sujeitos de fato e de direito, denominados governos não centrais, situados na dimensão subnacional dos Estados.

Conforme Dal Ri,

a grande maioria da doutrina internacionalista da primeira metade do século XX contempla o que vem hoje sendo chamado de "comunidade territorial infraestatal", ou seja, dos Estados Federados, Lander, Regiões, Províncias, Departamentos e Municípios que se contextualizam como esferas de governo em uma escala hierárquica inferiores ao Estado ( DAL RI, 2010, p. 17).

A doutrina dominante à época era baseada em um estatalismo que projetava o Estado na estrutura hierárquica no cenário internacional, impedindo e ofuscando as comunidades infraestatais de reconhecimento internacional.

As Conferências de Paz de Haia, as duas guerras mundiais, a Liga das Nações e a ONU, as Conferências de Viena, a guerra fria e a globalização econômica influíram decisivamente ao longo do Século XX para a mudança da concepção da doutrina de direito internacional anteriormente baseada em uma visão estatalista exarcerbada. 
No final do século XX, a dinâmica imposta pela globalização de trocas, de comunicação e trânsito para além das fronteiras, abalou significativamente o conceito de soberania do Estado nacional delineado pela configuração da modernidade (DAL RI, 2010, p. 17). O conceito de soberania, pilar central do Estado, passou a ser duramente relativizado nas relações e no direito internacional, abrindo espaços para a afirmação de novos sujeitos de direito internacional. Houve o fortalecimento do campo de atividades das empresas transnacionais, das Organizações não governamentais e das pessoas coletivas - sujeitos situados na dimensão subnacional e local - governos não centrais (Estados, municípios e comunidades territoriais não estatais).

Os governos não centrais despontaram pelas suas atividades no âmbito da reconfiguração do cenário internacional, com o desenvolvimento de estratégias próprias de inserção internacional e de cooperação com outros sujeitos.

\subsection{Os Estados federados e comunidades não estatais nos ordenamentos europeus}

São federais os Estados que conjugam vários centros de poder político autônomo, correspondendo na atualidade a forma organizativa de Estado com maior prestígio, por responder às necessidades e aspirações fundamentais de nossa época (DALLARI, 2005, p. 255).

Consigna-se de plano a diferença existente entre Federalismo e Federação, a partir da concepção expressa por Reverbel:

Federalismo pode ser considerado o estudo genérico dos aspectos comuns a todo e qualquer sistema federal, a federação é o léxico que, além de indicar uma determinada ordem federal, permite variados estudos comparativos entre os Estados que adotam esta forma de Estado (REVERBEL, 2007, p. 39-64).

Quanto à Federação:

Federação revela, portanto, uma aplicação concreta, específica, pontual, do federalismo. Está centrada nos arranjos institucionais possíveis que permitem o deslocamento de competências do centro à periferia e da periferia ao centro. Trata especificamente dos órgãos componentes da federação e das inter-relações existentes entre eles. Todo este arcabouço associativo provém da ordem constitucional (REVERBEL, 2007, p. 43).

O Estado federal indica, antes de tudo, uma forma de Estado e não de governo, embora não se pode negar a existência de um relacionamento muito 
estreito entre a adoção da organização federativa e os problemas de governo (DALLARI, 2005, p. 255).

No que versa ao quadro que envolve a inserção internacional dos países no âmbito do direito no Continente Europeu, a partir de 1960, resta evidenciada, notadamente no sistema federal, que a autoridade e competências decisórias encontram-se divididas entre dois níveis de governo, sendo um nacional e outro subnacional. Em nível federal estaria a União, enquanto que no subnacional estariam os Estados membros ou Províncias, Cantões ou Länder. Ainda, não se pode desconsiderar as regiões no caso da Bélgica e França e as comunidades autônomas no caso da Espanha², entre outros.

No novo cenário internacional, os Estados estão sendo progressivamente forjados a dividir (DUCHACEK, 1990, p. 9) com entidades subnacionais uma parte de suas responsabilidades, notadamente em política internacional.

Na senda dos doutrinadores que se dedicam ao estudo do tema dos novos sujeitos do direito internacional, a abordagem subsequente objetiva apresentar os modos e os meios pelos quais se tem permitido e legitimado a alguns Estados federados e algumas comunidades territoriais não estatais a realizarem atividades com evidente impacto na comunidade internacional.

As normas que fundamentam a ação internacional dos principais Estados europeus e suas unidades constituem a base da análise a seguir apresentada.

\subsubsection{Os Länder da República Federativa da Alemanha}

O artigo 32 da Constituição da República Federal da Alemanha preceitua a permissão aos Länder ${ }^{3}$ celebrarem tratados internacionais sobre a matéria de sua competência, com o consentimento do Governo Federal:

(1) - Compete à Federação a gestão das relações com Estados estrangeiros.

[...]

(3) - Nos limites da própria competência legislativa e com o consentimento do Governo Federal, os Länder podem celebrar tratados com os Estados Estrangeiros. ${ }^{4}$

Não resta dúvida, pelo citado dispositivo inserido no parágrafo terceiro do artigo 32 da Constituição da República Federativa da Alemanha, de que o Länder, via tratado internacional, pode criar direitos e obrigações para aquela unidade da Federação.

Entretanto, persiste controvérsia na doutrina, relativo ao consentimento previamente manifestado pelo governo federal da Alemanha, o qual poderia gerar 
nulidade jurídica do tratado. O problema estaria vinculado à validade ou invalidade jurídica, haja visto que o consentimento do governo federal permaneceria.

Dal Ri aponta que para evitar eventuais conflitos de competência na celebração e tratados internacionais, o direito constitucional alemão faz as seguintes distinções entre competências:

competência de celebração, competência de transformação e competência de ordens de execução, sendo que a Federação seria “[...] competente, conforme parágrafo primeiro, a celebrar tratados/ acordos em todas as áreas do direito internacional”. Mesmo em matéria de "[...] prevista competência dos Länder, segundo o parágrafo terceiro, não ocorre de maneira alguma a exclusão da competência concorrente da Federação (mesmo em competências diretas do Länder). Mas falta à Federação" [...] fora de suas competências de legislação regulamentar a competência de execução (DAL RI, 2010, p. 38).

Ainda, no que tange ao parágrafo terceiro do artigo 32 da Constituição alemã, para evitar política exterior paralela, torna-se essencial um contato estreito com o governo federal por parte do Länder.

A Convenção de Lindau, assinada em 1957 entre a Federação e os Länder, estabeleceu que a Federação poderia celebrar tratados em matérias nas quais não possuía competência, porém adstrita a alguns casos limitados. Quando não adstrita às limitações especificadas, a Federação subordina-se ao consentimento dos Länder no que versa à celebração de tratados sob competência exclusiva destes, cuja anuência é manifestada antes que o tratado se torne obrigatório às partes na esfera internacional (DAL RI, 2010, p. 39-40).

A Alemanha situa-se no centro da Europa e os Länder localizam-se em sua maioria na fronteira com Estados europeus, fato que concorre para uma maior inserção internacional, aliada aos estreitos laços internacionais econômicos e culturais. A participação dos Länder nas discussões sobre os temas e rumos da União Europeia constitui fator importante no aumento de atividades dos Länder no contexto europeu.

Entre as práticas que respaldam a ação dos Länder no direito internacional, pode-se incluir a criação de escritórios de representação no exterior, projetos de cooperação transfronteiriça, engajamento de autoridades em atividades de marketing no mercado global, participação na política externa da Alemanha e União Europeia (UE), participação em OIGs, participação em acordos e tratados bilaterais e multilaterais (com destaque para a ratificação e conclusão), participação na elaboração de memorandos e protocolos no sistema de tomada de decisões da UE. 
Não se pode negar de que os Länder são sujeitos jurídicos importantes do Direito internacional, considerado o grau de suas autonomias internas e externas, notadamente em assuntos próprios e desenvolvimento de atividades, acordos, ratificação e conclusão de tratados na integração da União Europeia.

\subsubsection{As comunidades e regiões da Bélgica}

A condição de Estado federal, composto por comunidades e regiões da Bélgica adveio em 1993 com a revisão constitucional, a qual provocou relevantes alterações na estrutura institucional do Estado e de seu funcionamento. Houve também significativas mudanças referente à competência em matéria internacional das comunidades e regiões. O compartilhamento entre governo federal e governo das comunidades e das regiões na condução das relações internacionais foi intensificado, respeitados os limites das suas respectivas competências. As unidades federais passaram a realizar negociações para celebração e conclusão de tratados com Estados soberanos, além de conferir consentimento sob matérias de competência de seu respectivo Conselho, participar de OIGs e representar o Estado Belga no âmbito dos Conselhos da União Europeia (DAL RI, 2010, p. 39).

A Bélgica pode ser considerada como país europeu com maior desenvolvimento e participação dos governos não centrais (comunidades e regiões belgas) em matéria internacional. Em conformidade com os artigos 2 e 3 do Reino da Bélgica, seis diferentes unidades constituintes compõem a estrutura federal belga: a Comunidade Francesa, a Comunidade de Flanders, a Comunidade Alemã, a Região de Wallonia, a Região de Flanders e a Região da Capital de Bruxellas. Portanto, a Bélgica é formada por uma estrutura federal dupla: as regiões econômicas e as comunidades criadas por razões de acentuado cunho cultural e linguístico (BURSENS; MASSART-PIÉRARD, 2009, p. 93).

O parágrafo primeiro do artigo 167 da Constituição do Reino da Bélgica estabelece que, mesmo cabendo ao Rei (governo central) dirigir as relações internacionais, este deve agir

[...] sem prejuízo da competência das comunidades e das regiões de regulamentar a cooperação internacional, compreendida a conclusão de tratados, para as matérias que são de sua competência pela Constituição ou em virtude desta ${ }^{5}$.

O parágrafo terceiro prescreve que os "[...] Governos de Comunidades e Regiões previstas no artigo 121 celebram, cada um no que lhe concerne, os tratados relativos às matérias que são de competências dos seus Parlamentos" 6 . Os tratados em tela [...] somente terão efeitos após terem recebido o consentimento do Parlamento"7. 
A normatização inserida no segundo e terceiro parágrafo do artigo 167 da Constituição complementa e integra o contido no parágrafo primeiro, referendando a afirmação de uma competência exclusiva das comunidades territoriais em celebrarem tratados que são de sua competência pela Constituição ou em virtude desta. Tal singularidade não possui semelhantes nos demais ordenamentos europeus. Pode-se afirmar de que em todos os outros sistemas jurídicos há competências concorrentes em que as comunidades, podendo assinar acordos com semelhantes estrangeiros, não excluem a possibilidade de o Governo Central fazer o mesmo nas mesmas áreas. As únicas exceções vinculam a necessidade de que os acordos firmados por comunidades e regiões respeitem as obrigações internacionais e supranacionais assumidas pelo Reino da Bélgica e que tais acordos sejam assinados apenas por Estados e Organizações Internacionais e que este reconheça e possua relações diplomáticas (DAL RI, 2010, p. 40).

O conteúdo normativo do artigo 16 da Lei Especial de Reformas Institucionais de 1980, mantido em vigor pela reforma constitucional de 1993 do Reino da Bélgica, merece destaque por regulamentar especialmente as competências em matéria internacional, de modo a conter dispositivos sobre o consentimento aos tratados, apresentação ao Conselho e previsão antecipada da possibilidade de responsabilização do Estado Belga internacionalmente. O parágrafo primeiro dispõe que "O consentimento aos tratados nas matérias que são de sua competência é dado pelo seu respectivo Conselho"8 (das comunidades e regiões). O parágrafo segundo estabelece que os tratados contemplados pelo parágrafo primeiro serão apresentados ao Conselho competente pelo respectivo governo. O parágrafo terceiro antecipa a possibilidade de que o Estado belga seja responsabilizado internacionalmente por atos e omissões derivantes de acordos assinados por comunidades e regiões que fazem parte do Reino. Em outros termos, o Estado belga pode substituir as comunidades e ou regiões belgas em caso de condenação destas por jurisdição internacional ou supranacional e devido ao não cumprimento de obrigação contraída. Por sua vez, o Estado belga, em situação inversa, também pode levar à jurisdição internacional ou supranacional qualquer sujeito de direito internacional por descumprimento de obrigações contraídas com qualquer de suas comunidades ou regiões (DAL RI, 2010, p. 41).

Relevante assinalar de que nas últimas décadas as comunidades e regiões belgas têm ampliado as suas competências em matéria internacional ${ }^{9}$, notadamente no campo cultural, econômico, ambiental, energético, creditício, trabalhos públicos (DAL RI, 2010, p. 42).

\subsubsection{A cooperação descentralizada e acordos pelas comunidades territoriais da França}

Com delineamentos diferenciados da normatização constitucional Alemã e da Constituição belga, a Constituição da República Francesa não estabelece 
nenhuma possibilidade de que as comunidades territoriais integrantes da República possam manter relações internacionais. $\mathrm{O}$ artigo 72 da Constituição da França considera as comunas, departamentos e territórios de ultramar como comunidades integrantes da República Francesa ${ }^{10}$.

A Constituição francesa aborda de forma geral a matéria que versa sobre as relações internacionais. O parágrafo segundo do artigo quinto preceitua que compete ao Presidente da República garantir a independência nacional, a integridade territorial e o respeito dos tratados ${ }^{11}$. O parágrafo primeiro do artigo 20 estabelece que compete ao governo conduzir a política da Nação, entre as quais a relações exteriores ${ }^{12}$.

A possibilidade de realização de 'cooperação descentralizada' foi regulamentada pela Lei $n^{\circ}$ 147, de 2 de fevereiro de 2007, a qual autorizou as comunidades territoriais a concluírem convenções com comunidades territoriais estrangeiras, condicionadas a respeitarem os compromissos assumidos pelo governo Central e os princípios fundamentais da República ${ }^{13}$.

A retrospectiva de participação antecedente das comunidades territoriais no trato da cooperação descentralizada remonta a Lei no 82.213 de 1982, emanada do parlamento francês e normativas vinculadas pelo gabinete do Primeiro Ministro. O contexto do surgimento da referida lei foi antecedido por tratados internacionais firmados pelo Estado Francês em matéria de cooperação fronteiriça (DALRI, 2010, p. 43). Em específico, o parágrafo terceiro do artigo 65 da anunciada lei dispõe que o Conselho pode “[...] decidir, com autorização do governo, organizar para fins de concertação e no âmbito da cooperação transfronteiriça, contatos regulares com coletividades descentralizadas estrangeiras tendo uma fronteira comum com a região"14.

$\mathrm{O}$ anunciado dispositivo de lei é extremamente restritivo, uma vez que estabelece competência em matéria de relações internacionais apenas para regiões administrativas, excluindo os departamentos e comunas. Além do mais, as relações de cooperação transfronteiriça restariam limitadas àquelas regiões de fronteira, com exclusão das regiões centrais da França.

Entretanto, com o objetivo de fortalecer a influência da França no planeta, a circular inicial do primeiro ministro, dirigida aos representantes do governo francês junto às regiões, departamentos e comunas, reconheceu publicamente o interesse e a importância da ação das comunidades territoriais em matéria internacional, porém, submetidas a monitoramento de representantes de missões diplomáticas e consulares francesas no exterior ( DAL RI, 2010, p. 43-44).

O alargamento de competência realizada pela circular anunciada foi notória,visto que esta extrapolou em muito o contido na Lei no 82.213 de 1982 . Referida circular, no dizer de Dal Ri, partiu do pressuposto de que a política de descentralização do governo teria ampliado o alcance da norma jurídica de 1982. $\mathrm{O}$ texto da circular incluiu atribuições de competências e meios incrementados às 
coletividades locais, objetivando afirmar sua identidade e desenvolver atividades em diferentes áreas de domínio, podendo ser chamadas a manter contatos com coletividades locais de outros países (DAL RI,2010, p.44). Referida ampliação de competências às comunidades territoriais infraestatais da França coincide com o contexto da assinatura da Convenção-quadro Europeia sobre a Cooperação Transfronteiriça ${ }^{15}$, em consonância explicitada pela circular no 2.063 , de maio de 1985 e extensão do artigo 65 da Lei 82.213/82.

A circular de maior destaque foi a editada pelo primeiro ministro francês Jacques Chirac, de 12 de maio de 1987, declaratória do fracasso das tentativas anteriores de monitoramento das iniciativas das comunidades territoriais no cenário internacional. $\mathrm{O}$ governo francês busca redefinir sua estratégia ao afirmar da necessidade de especificar em um texto particular as regras aplicáveis a estas relações. O governo deixa claro que a apresentação e negociação de projetos no contexto internacional é de competência exclusiva do Estado (SANTA CATARINA, 2010, p. 45-46).

Novo fundamento jurídico para a matéria adveio com a Lei $\mathrm{n}^{\circ} 92.125$, de 6 de fevereiro de 1992, a qual estabeleceu no artigo 131 que "As coletividades territoriais e seus agrupamentos podem concluir convenções com coletividades territoriais estrangeiras e seus agrupamentos, nos limites de suas competências e no respeito dos compromissos internacionais da França. A nova ordenação jurídica objetivou conferir uma relação mais articulada contendo limites bem definidos para servir como referência à expansão da cooperação descentralizada pelas comunidades territoriais da França (DAL RI, 2010, p. 46-47).

Em 26 de maio de 1994 foi editada circular conjunta entre o Ministro de negócios estrangeiro e o Ministro do Interior, especificando que para os fins previsto na Lei $\mathrm{n}^{\circ}$ 92.125/92, podem ser enquadradas somente as ações de coletividades territoriais de países diferentes para iniciativa de interesse público local ou para gerar serviços públicos. O governo colocou novamente sob guarda as instituições públicas de natureza subnacional, de forma pouco diplomática ante a ampliação das atividades das comunidades territoriais francesas no exterior nas décadas de oitenta e noventa do século passado. À época, a temeridade do governo dirigiu-se para a colisão entre o crescente número de acordos assinados pelas comunidades territoriais francesas e os princípios fundamentais da República ou tratados por esta firmados (DAL RI, 2010, p. 47).

Em 25 de Janeiro de 2007 a Assembleia Nacional, por unanimidade, aprovou a Lei 147, sem muitas inovações em relação a legislação anterior, a qual, em seu artigo L. 1115-1, limitou a possibilidade de, em caso de justificada urgência, as coletividades territoriais e seus agrupamentos passarem a poder realizar ou financiar ações de caráter humanitário.

A Lei no 773, de 7 de julho de 2014, via seu artigo 14, modificou a redação anterior do artigo 1115-1 da Lei 147/2007, estabelecendo que 
Em conformidade com os compromissos internacionais da França, as autoridades locais e as suas organizações podem implementar esforços ou apoiar anualmente ou plurianualmente ações de cooperação internacional, ajuda ao desenvolvimento ou humanitária. Para este fim, as autoridades locais e os seus agrupamentos podem, se for caso disso, celebrar acordos com as autoridades locais estrangeiras. Estes acordos especificam as acções propostas e o montante estimado dos compromissos financeiros. Eles entrarão em vigor imediatamente a sua transmissão à representante do Estado nos termos dos artigos L. 2131-1, L. 2131-2, L. 3131-1, L. 3131-2, L. 4141-1 et L. 4141-2. Os artigos, L. 3132-1 et L. 4142-1 são aplicáveis ${ }^{16}$.

Portanto, a lei francesa em vigor a partir de 2014 ampliou as possibilidades para as autoridades locais e os seus agrupamentos apoiarem ações de cooperação internacional e celebrar acordos com as autoridades locais estrangeiras, nos limites especificados em lei.

\subsubsection{As iniciativas das comunas e governos infraestatais da Itália}

A Constituição da República Italiana versa sobre a temática objeto no artigo 117, estabelecendo que "A potestade legislativa é exercitada pelo Estado e pelas Regiões no respeito da Constituição, assim como dos vínculos derivantes do ordenamento comunitário e das obrigações internacionais"17.

O parágrafo terceiro do artigo 117 prescreve: "São matérias de legislação concorrente aquelas relativas a: relações internacionais e com a União Europeia das Regiões; [...]"18. O parágrafo quarto dispõe que "Concerne às Regiões a potestade legislativa em referência a toda matéria não expressamente reservada à legislação do Estado"19. Em continuidade, o parágrafo quinto do artigo 117 estabelece dois princípios centrais: o princípio da participação das Regiões na fase ascendente de formação do direito comunitário nas matérias de competência regional e o princípio da competência regional na implementação e execução nas mesmas matérias dos atos jurídicos e da União Europeia e dos acordos internacionais, respeitados os procedimentos e normas regulamentares para o exercício do poder substitutivo $^{20}$. Ainda, o nono parágrafo prescreve que as Regiões "Nos limites de suas próprias competências, as Regiões podem concluir acordos com os Estados e acordos com entes territórios internos de outro Estado, nos casos e com as formas disciplinadas pelas leis do Estado" ${ }^{21}$.

A regulamentação normativa específica para as iniciativas tomadas pelas comunas e pelos governos infraestatais foi sedimentada pelo Decreto Presidencial de 31 de março de 1994 e Lei no 131/2003. Com base nas referidas normas, o Ministério dos Negócios da República Italiana elaborou documento contendo diretivas procedimentais para reger tais iniciativas, subscritas por interesse do Estado Italiano. As iniciativas envolvendo acordos entre Regiões e Estados estrangeiros 
sujeita a notificação prévia do Ministério do Exterior, e as iniciativas e pactos entre as cidades irmãs ficam sujeita a notificação prévia do Departamento de Negócios Regionais da Presidência do Conselho (SANTA CATARINA, 2010, p. 49).

O documento governamental denominado "Linee guida sulle procedure per accordi programatici, intense, gemellaggi”, além das diretivas para as iniciativas das comunas e dos governos infraestatais, fornece também a classificação dos atos internacionais implementados pelas referidas entidades subnacionais. As iniciativas se caracterizam pela contrapartida estrangeira, constituídas pelas entidades homólogas. Os acordos são constituídos pelos Estados e podem ser divididos na seguinte tipologia: executivos e aplicativos de acordos internacionais em vigor; acordos de natureza técnico-administrativa ou acordos de natureza programática (DAL RI, 2010, p. 50).

A importância do Decreto Presidencial de 1994 assume relevância pela definição precisa de atividades promocionais no exterior, incluindo aquelas desenvolvidas pelas Regiões e Províncias autônomas ${ }^{22}$ de Trento e Bolzano ${ }^{23}$ no âmbito das competências próprias e delegadas, além de distinguir "atividades promocionais no exterior" de "atividades de mero relevo internacional" (estudo e informação, visitas). Também, referido Decreto de 1994 regulamentou a colaboração do Estado e dos entes Públicos com as Regiões. O Artigo terceiro estabeleceu que as Regiões devem se Coordenar para a organização das mesmas com as representações diplomáticas e consulares do Estado. O artigo quarto forneceu a configuração das relações entre as Regiões Administrativas e Províncias com a Comunidade Europeia, motivo de controvérsia na península mesmo tendo seguido as diretrizes emanadas pelos órgãos da União Europeia (SANTA CATARINA, 2010, p. 50-53).

A controvérsia judicial decidida pela Corte Constitucional Italiana em abril de 2009, envolvendo as administrações das Províncias autônomas de Trento e Bolzano, acórdão n 425, de setembro de 2005, acabou por legitimar na prática as ações das coletividades territoriais na península. A decisão da Corte foi no sentido de que caberia ao Estado Italiano organizar, registrar e monitorar as iniciativas das regiões administrativas, províncias e comunas no âmbito internacional, fato que não impede que o governo continue a promover e facilitar tais iniciativas. Neste sentido o inciso III, do artigo $6^{\circ}$, da Lei 131/2003 se coaduna com a situação anunciada, uma vez que permite às Regiões e às Províncias autônomas de Trento e Bolzano, nas matérias de própria competência legislativa a concluir acordos executivos e aplicativos de acordos internacionais em vigor, acordos de natureza técnico-administrativa ou acordos de natureza programática executivos, sem prejuízo da tempestiva comunicação ao Ministério dos Negócios Exteriores e à Presidência do Conselho de Ministros - Departamento para os Negócios Regionais, nos termos previstos pelas normas de direito internacional geral e pela Convenção de Viena sobre direito dos tratados (DAL RI, 2010, p. 52-56). 
Destaca-se aqui que o inciso II, do artigo 6, da Lei 131/2003, prevê a possibilidade de celebração de acordos com “[...] entes territoriais internos de outro Estado, voltados a favorecer o desenvolvimento econômico, social e cultural, assim como realizar atividades de mero relevo internacional" 24 . Ainda, estabelece parâmetros obrigatórios que devem ser respeitados pelas Regiões e Províncias autônomas em compromissos e acordos celebrados, de modo a preservar a política exterior do Estado, encargos financeiros ou interesses de outros sujeitos, em compatibilidade ao artigo 14 da Constituição da República Italiana, inciso primeiro $^{25}$.

Por fim, registra-se que as Comunas, os governos e Regiões Administrativas Italianas buscam adequar a emanação de normas correspondentes à realidade $\mathrm{e}$ competências próprias, vinculativas às inciativas e demandas com significativo crescimento a partir da década de noventa.

\subsubsection{Outras ordenações Europeias - Áustria, Finlândia, Luxemburgo, Portugal, Suécia, Suíça}

Na Áustria os Länder são amparados juridicamente pelo artigo 16 da Constituição a concluir tratados com Estados fronteiriços com a Áustria ou com regiões que fazem parte de tais Estados. Semelhante ao direito constitucional alemão, a legislação austríaca, por meio do parágrafo segundo do artigo 16, impõe ao Presidente da junta executiva do Länder a obrigação de, antes de dar início às negociações, comunicá-las ao governo federal para regular consentimento antes da celebração do tratado. Considera-se tácito o consentimento se o governo federal não se manifestar dentro de oito semanas da data em que recebeu a solicitação de consentimento. $\mathrm{O}$ parágrafo terceiro do anunciado artigo 16 estabelece que, por solicitação do governo federal, os tratados devem ser denunciados e, em caso de não implementação da denúncia por parte da região, a competência passa a ser do governo federal (DAL RI, 2010, p. 57).

Açores e Madeira são regiões autônomas da República Portuguesa. Em conformidade ao artigo 227, letra ' $\mathrm{t}$ ” da Constituição Portuguesa, as regiões autônomas podem "Participar nas negociações de tratados e acordos internacionais que lhe digam respeito, bem como dos benefícios deles decorrentes". Trata-se de exceção, pois o artigo 135, letra 'b" estabelece que "Compete ao Presidente da República, nas relações internacionais, ratificar tratados internacionais, depois de devidamente aprovados". Ainda, o artigo 161, letra “i” dispõe que "Compete à Assembleia da República, aprovar tratados, designadamente os tratados de participação de Portugal em organizações internacionais, os tratados de amizade, de paz, de defesa, de retificação de fronteiras e os respeitantes assuntos militares, bem como os acordos internacionais que versem matérias de sua competência reservada ou que o governo entenda submeter à sua apreciação". 
A Suíça (Confederação Helvética) é um país singular no contexto europeu, pois encontra-se fora do alcance da legislação comunitária, não fazendo parte dos tratados constitutivos. A Constituição Federal, via artigo 56, concede aos Cantões a autorização para celebrarem acordos e tratados internacionais:

1 Os Cantões podem celebrar tratados com o estrangeiro nos domínios que digam respeito a sua competência.

2 Estes tratados não devem ser contrários nem ao direito, nem aos interesses da Confederação, nem ao direito de outros Cantões. Antes de celebrar um tratado os Cantões devem informar a Confederação. 3 Os Cantões podem tratar diretamente com as autoridades estrangeiras de condição inferior; nos outros casos, as relações dos Cantões com o estrangeiro acontecem por intermédio da Confederação (DAL RI, 2010, p. 58).

A citada autorização aos Cantões para celebrarem acordos e tratados internacionais é uma exceção na Constituição Helvética. Os artigos 166 e 184 da referida Constituição, respectivamente, estabelecem a competência primária, atribuindo à Assembleia Federal e ao Conselho Federal, no que abrange as relações exteriores e celebração de tratados internacionais.

Os Cantões sempre se vinculam a todas as matérias de política exterior realizadas pela Confederação que venham a abranger os interesses e as competências dos Cantões, a teor do artigo 55 da Constituição Federal.

A Constituição do Reino da Suécia, no que tange as relações com outros Estados, em seu artigo 3, capítulo X, assemelha-se ao contido nas Constituições da Alemanha e Bélgica. Entretanto, a delegação de poderes do governo, relativa à matéria de relações internacionais, ocorre somente para outros órgãos estatais, com exclusão das coletividades territoriais, províncias, regiões e municípios (SANTA CATARINA, 2010, p. 58).

As relações internacionais do Estado no Reino da Holanda são centralizadas e desconhecem a cooperação descentralizada francesa ou as possibilidades previstas nas constituições belga e da Alemanha, consoante informam o artigos 90 e 96 da Constituição do país.

As Constituições da Finlândia (parágrafos 93 e 97), da Dinamarca (artigo 19) e do Grão Ducado de Luxemburgo (artigo 37 e 49a) consignam competência dos governos centrais em matéria de relações internacionais.

\subsection{Os Municípios brasileiros}

A história da Federação no Brasil está diretamente vinculada à formação sócio-política, econômica, jurídica e cultural da Sociedade Brasileira. Referida formação insere a emancipação política, a progressiva formação econômica, a 
edificação das instituições sociais, da normatividade constitucional e da cultura do povo brasileiro.

No caso do Brasil, houve a adoção constitucional da forma Republicana de governo e da federação como forma de Estado ${ }^{26}$. O Estado para melhor atingir seus objetivos tende a adotar subdivisões internas com distribuição de competências e atribuições, o que é o caso da República Federativa do Brasil integrada pela União Federal, Estados membros, Distrito Federal e Municípios.

Na Federação os entes integrantes são dotados de capacidade política e na condição de Pessoas Jurídicas podem legislar criando normas abstratas com força vinculante no ordenamento jurídico.

A repartição de competências entre os entes da Federação pode ocorrer na dimensão constitucional ou administrativa. Uma vez estabelecidas as competências, os entes integrantes da Federação passam a legislar e atuar em todas as matérias envolvendo a sua esfera de delegação.

A federação brasileira teve seu referencial inicial estruturante a partir da Constituição de $1891^{27}$, com forte influência, à época, do modelo adotado pela Constituição dos Estados Unidos da América.

No contexto atual, a federação brasileira encontra-se em pleno fortalecimento político-administrativo, com destaque para a cooperação ${ }^{28}$ entre a União Federal, Estados membros, Distrito Federal e seus cinco mil quinhentos e setenta municípios.

Por conseguinte, o Brasil integra o grupo de países que na contemporaneidade adotaram o modelo federativo, ao lado de Estados, a exemplo dos Estados Unidos da América, Canadá, Alemanha, Argentina e Venezuela, entre outros.

A própria Constituição estabelece as matérias próprias de cada um dos entes da Federação, podendo acentuar a concentração de poderes ora na União ou nos Estados membros e Municípios.

No caso do Brasil,

Art. $4^{\circ}$. A República Federativa do Brasil rege-se nas suas relações internacionais pelos seguintes princípios: I - independência nacional; II - prevalência dos direitos humanos; III - autodeterminação dos povos; IV - não-intervenção; V - igualdade entre os Estados; VI defesa da paz; VII - solução pacífica dos conflitos; VIII - repúdio ao terrorismo e ao racismo; IX - cooperação entre os povos para o progresso da humanidade; $\mathrm{X}$ - concessão de asilo político. Parágrafo único. A República Federativa do Brasil buscará a integração econômica, política, social e cultural dos povos da América Latina, visando à formação de uma comunidade latino-americana de nações (BRASIL, 2015). 
O texto constitucional estabeleceu o rol taxativo de princípios ${ }^{29}$ que a República Federativa do Brasil deve primar nas relações internacionais, além de buscar a integração nas esferas econômica, política, social e cultural, objetivando a formação de uma Comunidade Latino Americana de Nações ${ }^{30}$.

Para Seitenfus,

[...] a atuação externa dos Estados e dos outros atores internacionais não pode ser compreendida sem a devida análise das condições internas que a motivam. Ou seja, existe um estreito vínculo entre a percepção ideológica de um governo e sua atuação internacional. Mesmo podendo ser consideradas como a mais constante das políticas públicas, as atividades externas governamentais sofrem inflexão de prioridades quando há mudança de governo ou de regime político [...] Portanto, há estreitos liames entre realidade interna e política externa (SEITENFUS, 2004, p. 43).

O art. 21 da Constituição Federal Brasileira estabelece que é competência da União manter relações com outros Estados estrangeiros, através da celebração de tratados internacionais. Nas relações internacionais, a União não atua como ente federado parcial, como componente da federação brasileira, mas congrega todos os demais entes federados para representar a República Federativa do Brasil. Portanto, a União ora atua como ordem jurídica global, representando o Estado brasileiro, ora como ente federado, como pessoa jurídica de direito público interno.

$\mathrm{Na}$ federação, a repartição de competências entre os entes pode ocorrer na dimensão constitucional ou administrativa. Os entes integrantes da Federação podem legislar e atuar em todas as matérias envolvendo a sua esfera de delegação.

Na definição de José Afonso da Silva, competência é a 'faculdade juridicamente atribuída a uma entidade, órgão ou agente do poder público para emitir decisões. Competências são as diversas modalidades de poder que servem aos órgãos ou entidades estatais para realizar suas funções (SILVA, 1992, p. 419).

A própria Constituição estabelece as matérias próprias de cada um dos entes da Federação, podendo acentuar a concentração de poderes ora na União ou nos Estados membros e Municípios.

No que se refere às competências dos municípios, a Constituição da República Federativa do Brasil, assim estabelece:

Art. 30. Compete aos Municípios: I - legislar sobre assuntos de interesse local; II - suplementar a legislação federal e a estadual no que couber; III - instituir e arrecadar os tributos de sua competência, bem como aplicar suas rendas, sem prejuízo da obrigatoriedade de prestar contas e publicar balancetes nos prazos fixados em lei; IV - 
criar, organizar e suprimir distritos, observada a legislação estadual; $\mathrm{V}$ - organizar e prestar, diretamente ou sob regime de concessão ou permissão, os serviços públicos de interesse local, incluído o de transporte coletivo, que tem caráter essencial; VI - manter, com a cooperação técnica e financeira da União e do Estado, programas de educação infantil e de ensino fundamental; VII - prestar, com a cooperação técnica e financeira da União e do Estado, serviços de atendimento à saúde da população; VIII - promover, no que couber, adequado ordenamento territorial, mediante planejamento e controle do uso, do parcelamento e da ocupação do solo urbano; IX - promover a proteção do patrimônio histórico-cultural local, observada a legislação e a ação fiscalizadora federal e estadual (BRASIL, 2016).

Com a Constituição de 1988 o município teve ampliado sua autonomia quanto ao campo de competências de atuação, com destaque para legislar, com fundamento na independência constitucional que lhe é inerente sobre os assuntos referidos no artigo 30, I, II, III, IV da CF. Também, em matéria organizacional, o município tem competência administrativa sobre os assuntos dos incisos IV, V, VI da CF. Além disso, o município possui competência quanto à promoção humana e da promoção do patrimônio histórico, conforme dispõe o artigo 30, VII, VIII, IX da CF.

Ataliba Nogueira defende que não há município com vida, se as autoridades nele apenas residem e se as próprias autoridades locais esperam a palavra ou a ajuda, que venha de fora. Não há ninguém mais interessado nos assuntos locais do que os munícipes. Sem independência não há efetiva autonomia política, econômica e financeira dos Municípios. Este mesmo autor deixa transparecer, em sua teoria, que a existência autônoma do município é condição real e efetiva para que referido ente seja sujeito efetivo de direito, cabendo apenas o reconhecimento formal pela lei do Estado (NOGUEIRA, 2011, p. 840-841).

\subsubsection{A ampliação da atuação internacional dos municípios brasileiros}

O processo da globalização ${ }^{31}$ provocou uma reconfiguração do papel do Estado-Nação e da atuação dos blocos econômicos regionalizados (ALMEIDA, 1998, p. 178-184). À medida que se avança para além da dimensão territorial nacional, emerge a dimensão internacional/transnacional, embora não separada do direito interno.

Destaca-se aqui o fortalecimento dos governos subnacionais ${ }^{32}$ que interessa ao estudo das relações internacionais, dos processos de integração, da globalização, do federalismo e dos temas municipais e estaduais. 
Todavia, a ampliação da atuação ${ }^{33}$ dos municípios brasileiros no cenário internacional, notadamente daqueles situados em faixa de fronteira, foi intensificada a partir da projeção das cidades no direito e relações internacionais, com forte impulso com a globalização a partir dos anos 90, das conferências internacionais ${ }^{34} \mathrm{e}$ processos de integração regional ${ }^{35}$ que possibilitaram a abertura de novos espaços de atuação para o poder local firmar-se na cena internacional.

Cena internacional que evidencia a importância e atualidade do debate das cidades e o direito internacional, a exemplo do Congresso "Les Villes et le Droit Internacional" realizado em 03 de junho de 2016 na Université Paris Naterre" (LES VILLES, 2016).

No Brasil, a Constituição da República Federativa de 1988 atribuiu status de ente federativo aos municípios, em igualdade às demais organizações políticoadministrativas reconhecidas, assegurando-lhes autonomia ${ }^{36}$. Autonomia municipal nos aspectos: político, administrativo, financeiro, legislativo e autoorganizatório. (artigos 29 a 31, 156, 158 e 159 da CF). Possibilitou ao município editar sua lei orgânica própria; extinguiu a nomeação de prefeitos pelos governadores e manteve a eleição direta de vereadores (art. 29, CF); atribuiu competência privativa para legislar sobre interesse local (art. 30, I, CF); ampliou a competência impositiva para criar tributos (art. 156, CF); e aumentou a participação municipal nos impostos partilhados (artigos 158 e 159, $\$ 3^{\circ}$, da CF).

Também é notório que o Ministério das Relações Exteriores Brasileiro tem celebrado convênios de cooperação com governos estaduais e municipais, secretarias estaduais, universidades e outros tantos agentes locais para promover o debate sobre temas internacionais de interesse do Estado e da federação ${ }^{37}$.

Destaca-se aqui o esforço decisivo dos agentes locais na instrumentalização dos programas e agendas, em conformidade à vocação e possibilidades para a ação externa, a exemplo da implementação de cursos destinados à sensibilização de determinados setores produtivos para as oportunidades do mercado externo.

No complexo processo de globalização, os sujeitos emergentes do direito internacional, incluídos os governos não-centrais, situados na dimensão subnacional, vêm gradualmente disputando e conquistando espaços da agenda internacional com os governos centrais e se consolidando como agentes da dinâmica internacional.

A integração regional dos Estados, o surgimento de empresas transnacionais com forte poder econômico, a desintegração de alguns Estados, o avanço e unificação tecnológica, evidenciam uma mudança significativa no desenvolvimento de atividades e modo de atuação no campo internacional/ transnacional.

O cenário anunciado evidencia a tendência de quebra do paradigma ${ }^{38}$ de que "tudo o que era relação com o exterior cabia à União Federal", típico de uma concepção de atuação dentro de uma visão centralmente estatalista. Entretanto, de 
forma complementar e não isolada e/ou desvinculada, no atual cenário, é evidente a ampliação do campo de atuação dos governos subnacionais e locais capazes de buscar recursos e formas próprias de realizar seus objetivos.

Estados e municípios passam a constituir uma importante ferramenta de incorporação e integração dos diferentes níveis da Federação Brasileira ao sistema internacional, contribuindo para a redução das desigualdades regionais e para o fortalecimento da integração nacional.

$\mathrm{Na}$ visão de Rodrigues, os movimentos dos Estados membros e municípios favorece e estimula a participação direta do poder local nas relações internacionais (RODRIGUES, 1998). Ribeiro destaca que a paradiplomacia dos municípios brasileiros vem aumentando gradativamente desde os anos 1980, porém, uma política externa federativa com inserções internacionais das unidades locais é registrada apenas a partir de 1990, em algumas grandes cidades do país (RIBEIRO, 2009).

A Conferência das Nações Unidas sobre Meio Ambiente e Desenvolvimento (ECO-92), em 1992, possibilitou a elaboração do Tratado por Cidades Justas, Democráticas e Sustentáveis. Em julho de 1996, a Conferência Habitat II, realizada em Istambul estabeleceu o direito à moradia adequada como direito humano - inscrito na Agenda Habitat. Essas Conferências contribuíram para o reconhecimento do direito à moradia na Constituição Brasileira como um direito fundamental, no ano 2000; a aprovação do Estatuto da Cidade, no ano de 2001 e a criação do Ministério das Cidades, fortalecendo a elaboração e execução de políticas urbanas com apoio dos diversos atores da sociedade civil (SAULE JÚNIOR, 2006, p. 18-25).

Não se pode negar que a participação das cidades brasileiras contribui decisivamente para o movimento de projeção das relações internacionais, em que pese a assimetria de atuação.

A Confederação Nacional dos Municípios (CNM) e a Frente Nacional de Prefeitos concorrem fortemente para a ampliação da capacidade de articulação interna e internacional dos municípios, a exemplo da Mercocidades e do Fórum de Secretários e Dirigentes municipais de Relações Internacionais.

Entre os casos brasileiros de municípios com maior destaque em ações internacionais pode-se inserir: Curitiba (Planejamento urbano), Porto Alegre (Orçamento Participativo e sede de eventos do Fórum social mundial), São Paulo (Estratégia Internacional voltada ao Direito e Relações Internacionais).

A criação da Assessoria para Assuntos Federativos e Parlamentares (AFEPA), vinculada ao Gabinete do Ministro das Relações Exteriores vincula o reconhecimento do governo federal em fazer uma interface entre o referido ministério e os governos de estados e municípios brasileiros. Referida política implicou a instalação de vários escritórios do Itamaraty em estados ou regiões do país, a exemplo do RS, PR, RJ, SP, MG, PB, AM. 
No Brasil avançam experiências importantes de municípios na criação de mecanismos com efetivo desenvolvimento de seu papel na produção do espaço glocal e internacional, a exemplo dos municípios de fronteira.

\subsubsection{0 parecer da proposta de Emenda Constitucional - PEC 475/2005 da paradiplomacia}

Digno de registro é o fato de começar a surgir propostas de mudanças normativas objetivando a construção e regulamentação de espaços de atuação internacional dos entes subnacionais brasileiros. Entre as propostas de Emenda Constitucional pode-se citar a PEC $475 / 2005^{39}$ da paradiplomacia ${ }^{40}$ de iniciativa do ex-deputado Federal André-Costa (PDT/RJ). Dada a importância da matéria, cita-se o teor do Parecer do Relator da PEC 475/2005:

A proposta ora encaminhada visa a acrescentar um parágrafo ao existente no artigo 23 do texto constitucional. Pela redação, os Estados, o Distrito Federal e os Municípios, no âmbito das respectivas competências, poderiam promover atos e celebrar acordos ou convênios com entes subnacionais estrangeiros, mediante prévia autorização da União, observando-se o previsto no artigo 49 e na forma da lei. Apresentada por número suficiente de signatários, vem a esta Comissão para que se manifeste quanto à admissibilidade. Não há óbices preliminares à emenda ao texto constitucional, atendido o disposto no $\$ 1^{\circ}$ do artigo 60 da Constituição da República. Para discorrer sobre o conteúdo da proposta, entendo correto abordar seus três pontos-chave: a) que atos internacionais os Estados, Distrito Federal e Municípios poderiam celebrar; b) com quem poderiam celebrar tais atos; c) quais as condições formais. A sugestão da emenda ao texto constitucional ora examinada parte do pressuposto que os entes públicos acima citados não podem, hoje, celebrar atos com pessoas jurídicas estrangeiras - e não podem exatamente porque faltaria a devida menção no texto constitucional. Discordo. Nada há no texto constitucional que impeça Estados, Distrito Federal e Municípios de celebrar atos internacionais (com pessoas físicas ou jurídicas, públicas ou privadas, contratos, acordos ou convênios, etc.). A liberdade de celebrar atos é decorrente da autonomia declarada no artigo 18 da Constituição da República e explicitada em outros artigos, como o 30. Sua liberdade é ampla e submissível a apenas dois limites: a) em casos onde o legislador constituinte deliberou restringi-la (vide artigo 52, inciso V); b) o próprio conjunto de competências atribuídas aos entes estatais pela Constituição da República. Assim, parcela componente da autonomia estatal não pode ser diminuída ou extinta, sob pena de avançar sobre a própria natureza jurídica dos entes estatais. De resto, certamente não caberia aos Estados, ao Distrito Federal ou aos Municípios celebrar, por exemplo, atos internacionais cujo tema seja 
nacionalidade ou moeda. Vemos, portanto, que a esses entes estatais é possível celebrar atos internacionais, sim, mas, naturalmente, dentro da esfera da respectiva competência. É possível celebrar tais atos com quaisquer pessoas estrangeiras, sejam elas dotadas ou não de personalidade jurídica de direito internacional. Estado, Distrito Federal e Municípios podem celebrar quaisquer atos com cidadãos, organizações oficiais ou não-governamentais ou quaisquer entes de natureza estatal (o País, a Província, o Departamento, o Condado, etc...). Para a prática de tais atos, os entes estatais não precisam de "autorização" da União, como sugerido na proposta. Autorizar, neste caso, é exercer poder sobre a vontade de outrem, e a Constituição da República não abriga muitos casos do exercício desse poder (um deles é a autorização do Senado para operações externas financeiras, já indicada). Assim, a sugestão de "autorização" viola a autonomia reconhecida aos entes estatais. Igualmente dispensáveis e criticáveis são a remissão ao artigo 49 (de resto imprecisa) e a previsão de lei para dispor sobre o tema. Nada no artigo 49 parece encaixar-se na discussão ora exposta (salvo, como mero elemento de comparação, o já citado inciso V). Estariam os Autores desejando submeter a "autorização" ao crivo do Congresso Nacional e sob a forma de "lei"? Seria, em minha opinião, apenas mais um detalhe equivocado de um mecanismo, ora sugerido, manifestamente contrário ao previsto no texto constitucional. Pelo exposto, opino pela inadmissibilidade da PEC no 475, de 2005, por promover a subversão da ordem federativa ao restringir a autonomia estatal prevista no artigo 18 da Constituição da República. Sala da Comissão, em 29 de abril de 2006. Deputado NEY LOPES Relator (BRASIL, 2016).

O conteúdo do parecer citado respalda o reconhecimento por integrante do parlamento nacional brasileiro (Câmara dos Deputados) de que não há nada no texto constitucional que impeça Estados, Distrito Federal e Municípios de celebrar atos internacionais (com pessoas físicas ou jurídicas, públicas ou privadas, contratos, acordos ou convênios, etc.). A liberdade de celebrar atos é decorrente da autonomia declarada no artigo 18 da Constituição da República e explicitada em outros artigos, a exemplo do artigo 30 da Constituição.

Tal reconhecimento explicita materialmente a possibilidade do desenvolvimento de atividades pelos municípios brasileiros nas esferas internacionais, no âmbito de suas competências, sem a tutela da União Federal. Além disso, reafirma a personalidade jurídica ativa dos entes subnacionais, incluídos os municípios, a partir de seus vínculos com a ordem jurídica nacional, para atuarem na dimensão internacional/transnacional, fato que por si só não os torna sujeitos de direito internacional, em conformidade ao conceito em vigência no direito internacional público" ${ }^{41}$.

Por derradeiro, registra-se que a PEC 475/2005 da paradiplomacia foi arquivada em virtude da inexistência no texto constitucional de normativa que 
impeça Estados, Distrito Federal e Municípios de celebrar atos internacionais, nos termos do citado parecer.

\section{CONCLUSÃO}

As transformações provocadas pelo fenômeno da globalização nas últimas décadas do século XX influíram decisivamente para a induzida flexibilização do conceito da soberania, bem como dos entraves nacionais que subordinavam os Estados federados e comunidades ou governos infraestatais à imobilidade no desenvolvimento de atividades e silêncio no cenário internacional. Evidente que houve resistências por parte dos defensores da doutrina estatalista as quais foram enfrentadas com firmeza por parte de autores antiformalistas ainda na primeira metade do século XX.

$\mathrm{Na}$ contingência histórica do pós-guerra, década de 40 e 50 do século passado, alguns Estados Europeus com cultura política e equilíbrio interno de poder decidiram declinar parte de sua soberania em matéria de relações internacionais em favor de pessoas coletivas de direito público - Estados federados e comunidades ou governos infraestatais. A questão assumiu a dimensão do debate em nível constitucional. A Alemanha se constituiu como pioneira no compartilhamento de competência entre Estado e entidades territoriais de caráter público ao regular a matéria objeto no artigo 32 da Constituição da República Federal. Tal reconhecimento jurídico incidiu fortemente sobre a doutrina do direito internacional, potencializando o debate sobre a possibilidade de efetiva concessão de personalidade jurídica internacional aos denominados governos não centrais.

Consigna-se que a doutrina internacionalista ainda não sedimentou uma resposta adequada para a imputação de direitos e obrigações às comunidades infraestatais, considerados os elementos que determinam a condição de reconhecimento da personalidade jurídica internacional aos sujeitos de direito internacional. Ao mesmo tempo que se reconhece direitos às comunidades infraestatais, persiste a dificuldade em reconhecer obrigações a serem assumidas por referidas comunidades. A problemática evidencia-se mais claramente no que concerne à assinatura de tratados internacionais, cuja responsabilidade em última instância recai ao Estado que possui a tarefa de zelar pelo cumprimento dos tratados. Entretanto, ao reconhecer-se o direito das comunidades infraestatais em firmar acordos e tratados, transparece possível a concessão de personalidade jurídica internacional às referidas pessoas coletivas de direito público.

Por outro lado, as comunidades infraestatais se constituem como candidatas a sujeitos de direito internacional, notadamente pelas suas necessidades, desenvolvimento de atividades nas relações internacionais e por possuírem elementos característicos do Estado (território, governo, população). Além disso, 
são concorrentes substitutas direta do Estado no cenário internacional em caso de profunda crise político-institucional ou de controle das forças políticas internas.

O compartilhamento de competências entre Estado e entidades territoriais de caráter público, no equilíbrio interno dos Estados, se fortalece cada vez mais no contexto da atual conjuntura política e econômica que liga o global ao local e vice-versa, provocadora de uma significativa flexibilização da soberania Estatal centralizada, em tempos de grandes mudanças de paradigmas. Em tal contexto se inserem também os municípios brasileiros, com destaque para aqueles situados em faixa de fronteira ou que mantêm algum tipo de atividade(s) nas relações e no direito internacional.

\section{NOTAS}

1 "Il s'agit de collectivités ou sens où eles disposent d'une personalité juridique propre. L'existence de cette personalité juridicque en droit interne ne soulève guère de discussion. En revanche se pose la question de savoir si elles disposent ou si elles disposeront um jour, pour autant que cela paraisse nécessaire, de la personalité juridique internacionale. Il s’agit de colletivités publiques. Elles sont chargées de la gestion d'intérêts collectifs et sont régies,généralement, par le droit public. Elles sont gérées le plus solvente, par des élus du peuple et disposent ainsi d’un degré de légitimité importante. Il s'agit de colletivités publiques territoriales. Elles se distinguent des establissements publics qui n’ont pas de compétences relatives à un espace territorial circonscrit. Les découpages procedentes tantôt de la géographie, tantôt de l'histoire. Ils tiennent compte de l'économie, de la culture et de la volunté publique". In: JOS, Emmanuel. Collectivités territoriales non-étatiques et système juridique internacional dans le contexte de la mondialisation (JOS,2002, p.9; DAL RI, 2010, p. 23).

2 A Espanha possui uma forma organizativa de Estado que pode ser considerada de Estado Regional, menos centralizada do que o Estado Unitário, porém, sem chegar aos extremos de descentralização do federalismo. O mesmo pode-se afirmar em relação à Itália (DALLARI, 2005, p.255).

3 A Alemanha comporta dezesseis Länder e, entre os quais, três cidades-Estados: Berlim, Hamburgo e Bremen. Os Länder diferem em tamanho, população e em desempenho econômico. In: HRBEK, Rudolf. Federal Republic of Germany (MICHELLMANN, 2009. p. 143).

4 "Die Pflege der Beziehungen zu auswärtingen Staaten ist Sache des Bundes. [...] (3) Soweit die Länder für die Gesetzgebung zuständig sind, könnnen sie mit Zustimmung de Bundesregierung mit auswärtigen Staaten Verträge abschliessen".

5 “Art. 167. $\$ 1^{\circ}$. Le Roi dirige les relations internationales, sans préjudice de la compétence des communautés et des régions de régler la coopération internationale, y compris la conclusion de traités, pour les matières qui relèvent de leurs compétences de par la Constitution ou en vertu de celle-ci”(LA CONSTITUCION BELGE, 2016).

6 “Art. 167. $\$ 3^{\circ}$. Les Gouvernements de communauté et de région visés à l'article 121 concluent, chacun pour ce qui le concerne, les traités portant sur les matières qui relèvent de la compétence de leur Parlement" (LA CONSTITUCION BELGE, 2016).

7 “Art. 167. \$ 3. [...] Ces traités n’ont d’effet qu’après avoir reçu l’assentiment du Parlement" (LA CONSTITUCION BELGE, 2016).

8 "Lassentiment aux traités dans les matières qui relevent de sa compétence, est donné par le Conseil concerne". 
9 A título exemplificativo, a região da Wallonia ampliou sua participação em matéria internacional para garantir o desenvolvimento econômico e tecnológico, com exportações de produtos e atração de investimento interno. Paralelamente, a comunidade de Flanders prioriza o desenvolvimento econômico regional e o desenvolvimento científico e tecnológico (LEJEUNE; SOLDATOS, 1990. p. 142-175).

10 "Les collectivités territoriales de la République sont les communes, les départements, les régions, les collectivités à statut particulier et les collectivités d’outre-mer régies par l'article 74 . Toute autre collectivité territoriale est créé par la loi, le cas échéant en lieu et place d'une ou de plusieurs collectivités mentionnées au présent alinéa". TEXTE INTÉGRAL de la Constitution du 4 octobre 1958 en vigueur (TEXTE INTÉGRAL, 2016)

11 "Le Président de la République veille au respect de la Constitution. Il assure, par son arbitrage, le fonctionnement régulier des pouvoirs publics ainsi que la continuité de l'État. Il est le garant de l'indépendance nationale, de l'intégrité du territoire et du respect des traités" (TEXTE INTÉGRAL,2016).

12 "Le Gouvernement détermine et conduit la politique de la nation. Il dispose de l'administration et de la force armée" (TEXTE INTÉGRAL,2016).

13 Princípios da indivisibilidade da República e da soberania nacional, atribuições confiadas ao Estado pela Constituição francesa (art. 2 e 3) e pela lei.

14 "[...] decidir, avec l'autorisation du governement, d’organiser, à des fins de concertation et dans le caddre de la coopération transfrontaliére, des contacts réguliers avec des collectivités descentralisées étrangères ayant une frontière commune avec la région".

15 "A Convenção-Quadro Europeia representa assim o coroar do esforço desenvolvido pelo Conselho da Europa através da CPPLR no sentido de levar os Estados a reconhecerem a necessidade e utilidade da cooperação transfronteiriça. É com base neste instrumento que, em diversos países europeus, quer Estados-membros da então CEE e da atual União Europeia, quer outros Estados que não integram a União, os poderes locais e regionais- ou, para usarmos a expressão ConvençãoQuadro, as Coletividades ou Autoridades Territoriais-, situados de um e outro lado das respectivas fronteiras, celebram acordos de cooperação transfronteiriça, com enorme vantagens para suas populações" (SANTA CATARINA, 2010, p. 129-130).

16 "Modifié par LOI no 2014-773 du 7 juillet 2014 - art. 14 (V). Dans le respect des engagements internationaux de la France, les collectivités territoriales et leurs groupements peuvent mettre en œuvre ou soutenir toute action internationale annuelle ou pluriannuelle de coopération, d'aide au développement ou à caractère humanitaire. A cette fin, les collectivités territoriales et leurs groupements peuvent, le cas échéant, conclure des conventions avec des autorités locales étrangères. Ces conventions précisent l'objet des actions envisagées et le montant prévisionnel des engagements financiers. Elles entrent en vigueur dès leur transmission au représentant de l'Etat dans les conditions fixées aux articles L. 2131-1, L. 2131-2, L. 3131-1, L. 3131-2, L. 4141-1 et L. 4141-2. Les articles L. 2131-6, L. 3132-1 et L. 4142-1 leur sont applicables" (ARTICLE L1115-1, 2016 ).

17 "La potestà legislativa è esercitata dallo Stato e dalle Regioni nel rispetto della Costituzione, nonchè dei vincoli derivanti dall'ordinamento comunitario e dagli obblighi internazionali" (COSTITUZIONE DELLA REPUBBLICA ITALIANA,2016).

18 "Sono materie di legislazione concorrente quelle relative a: rapporti internazionali e com l'Unione europea delle Region” (COSTITUZIONE DELLA REPUBBLICA ITALIANA,2016).

19 "Spetta alle Regioni la potestà legislativa in riferimento ad ogni materia non espressamente riservata alla legislazione dello Stato"(COSTITUZIONE DELLA REPUBBLICA ITALIANA, 2016).

20 "Le Regioni e le Province autonome di Trento e di Bolzano, nelle materie di loro competenza, partecipano alle decisioni dirette alla formazione degli atti normativi comunitari e provvedono all'attuazione e all'esecuzione degli accordi internazionali e degli atti dell'Unione europea, nel 26 
rispetto delle norme di procedura stabilite da legge dello Stato, che disciplina le modalità di esercizio del potere sostitutivo in caso di" "(COSTITUZIONE DELLA REPUBBLICA ITALIANA, 2016)..

21 "Nelle materie di sua competenza la Regione può concludere accordi con Stati e intese con enti territoriali interni ad altro Stato, nei casi e con le forme disciplinati da leggi dello Stato" (COSTITUZIONE DELLA REPUBBLICA ITALIANA, 2016).

22 Sobre autonomia das entidades territoriais, regionalismo e poder externo do Estado, vide também: PERGOLA, Antonio La et al. Regionalismo, federalismo e poder externo do Estado: o caso italiano e o direito comparado. Revista dos Tribunais - Doutrinas Essenciais, São Paulo, v. I, p. 645-688, 2012.

23 O parágrafo terceiro do artigo 117 da Constituição da República Italiana, estabelece que: "As Regiões e as Províncias autônomas de Trento e de Bolzano, nas matérias de sua competência, participam das decisões voltadas à formação dos atos normativos comunitários e provêm a atuação e a execução dos acordos internacionais e dos atos da União Européia, respeitando as normas de procedimento estabelecidas pela lei do Estado, que regulamenta as modalidades de exercício do poder substitutivo em caso de inadimplência"( COSTITUZIONE DELLA REPUBBLICA ITALIANA,2016).

24 “[...] enti territorial interno ad altro Stato, intense dirette a favorire il loro sviluppo econômico, sociale e culturale, nonché a realizare attivitá di mero rilievo internazionale”.

25 "I Comuni, le Province, le Città metropolitane e le Regioni sono enti autonomi con propri statuti, poteri e funzioni secondo i principî fissati dalla Costituzione" (COSTITUZIONE DELLA REPUBBLICA ITALIANA, 2016).

26 "Art. $1^{\circ}$. A República Federativa do Brasil, formada pela união indissolúvel dos Estados e Municípios e do Distrito Federal, constitui-se em Estado Democrático de Direito e tem como fundamentos: I - a soberania; II - a cidadania; III - a dignidade da pessoa humana; IV - os valores sociais do trabalho e da livre iniciativa; V - o pluralismo político" (BRASIL, 2016).

27 "Art. $1^{\circ}$. A Nação brasileira adota como forma de Governo, sob o regime representativo, a República Federativa, proclamada a 15 de novembro de 1889, e constitui-se, por união perpétua e indissolúvel das suas antigas Províncias, em Estados Unidos do Brasil ( BRASIL, 2016).

28 No que diz respeito a forma de cooperação entre os entes integrantes da República Federativa do Brasil, a Constituição Federal, assim dispõe: Art. 23. É competência comum da União, dos Estados, do Distrito Federal e dos Municípios. Parágrafo único. Leis complementares fixarão normas para a cooperação entre a União e os Estados, o Distrito Federal e os Municípios, tendo em vista o equilíbrio do desenvolvimento e do bem-estar em âmbito nacional; Art. 241. A União, os Estados, o Distrito Federal e os Municípios disciplinarão por meio de lei os consórcios públicos e os convênios de cooperação entre os entes federados, autorizando a gestão associada de serviços públicos, bem como a transferência total ou parcial de encargos, serviços, pessoal e bens essenciais à continuidade dos serviços transferidos.

29 "Os princípios cumprem caráter de fundamentalidade no sistema das fontes do direito, constituindo-se em normas de natureza ou com um papel fundamental no ordenamento jurídico devido à sua posição hierárquica no sistema das fontes”. (CANOTILHO, 1998. p. 1086-87).

30 O Mercosul foi criado em 1991, pelo Tratado de Assunção. Somente em 1995, com a entrada em vigor do Protocolo de Ouro Preto, os Estados decidiram criar a personalidade jurídica do Mercosul. Trata-se agora de uma Organização Internacional. O Mercosul tinha como membros originais Argentina, Brasil, Paraguai e Uruguai. Em 2005 houve a adesão da Venezuela, cuja efetivação necessita da concordância dos Parlamentos Nacionais (VARELA, 2011. p. 375).

31 Globalização significa desterritorialização; consequentemente, também significa a primazia da economia em detrimento da política; ademais, significa o eclipse do Estado e da sua expressão mais representativa, a soberania (GROSSI, 2010, p. 73). 
A globalização jurídico-política implica no deslocamento da capacidade de formulação, de definição e de execução de políticas públicas, antes radicada no Estado-Nação, para arenas transnacionais ou supranacionais, decorrente da globalização econômica e de seus efeitos sobre o alcance do poder soberano. (FREITAS, 1997, p. 73).

32 Não se pode negar no contexto atual a importância crescente da relação entre a dimensão subnacional e local (Estados e Municípios) e a integração regional e as relações internacionais. Os governos locais estão aumentando o seu papel protagônico no mundo, colocando problemas novos não apenas tocante ao federalismo, mas também aos Estados nacionais, que buscam adaptar-se às mudanças, entre outros ( VIGEVANI, 2010).

33 Neste sentido vide: CEZÁRIO, 2011.

34 Entre as conferências pode-se citar: as conferências da Organização das Nações Unidas (ONU), as relacionadas ao Meio Ambiente, do Fórum Social Mundial, entre outras.

35 Com a globalização, compreendida como uma linha contínua do local/regional para o global, houve a progressiva formação dos chamados blocos econômicos, a exemplo do North American Free Trade Agreement (NAFTA), União Europeia, Acordo de Livre Comércio das Américas (ALCA), Tigres Asiáticos, Mercado Comum do Sul (MERCOSUL), notadamente com atuação no campo econômico/comercial.

36 Autonomia: Refere-se à capacidade, competências e condições para suportar responsabilidades, desempenhar tarefas e alcançar objetivos à sua razão de ser. Significa também a independência legislativa e político-administrativa/executiva para decidir sobre as questões de sua esfera de competência.

37 Realça-se aqui os programas brasileiros de cooperação firmados pelo Ministério das Relações Exteriores, via Agência Brasileira de Cooperação, referentes à transferência de conhecimentos e tecnologias, dentro de acordos firmados entre países e organismos internacionais, com consequente envolvimento e execução pelos entes subnacionais como Estados e municípios. Neste sentido vide mapa onde a $\mathrm{ABC}$ atua em projetos de cooperação: www.abc.gov.br; www.itamaraty.gov.br.

38 Kuhn introduziu o conceito chave de paradigma na epistemologia ao versar sobre a história da ciência, caminhos, estrutura e mudanças. Para Kuhn os paradigmas científicos são modelos dos quais brotam as tradições coerentes e específicas da pesquisa científica ( KUHN, 2000). Para Faria, um paradigma,"implica uma teoria básica, uma tradição científica e algumas aplicações exemplares, que são aceitas pelos cientistas ao ponto de suspenderem o esforço crítico de discussão de seus pressupostos e de suas possíveis alternativas substitutivas". Sob a forma de explicações científicas os paradigmas expressam uma visão de mundo extremamente articulada. Os fundamentos de um paradigma se consolidam quando aceitos como verdade sistematizada por uma comunidade científica predominante em determinada época. (FARIA, 1988, p. 21). Para Rodrigues, um paradigma das relações internacionais é " uma visão, uma interpretação, uma perspectiva dos fenômenos internacionais ou mundiais, amparada em algum método, cuja pretensão é explicar e dar sentido para os fatos que estão se desenrolando no cenário internacional" (RODRIGUES, 1994. p. 18).

39 Nos últimos anos, pelo menos sessenta e cinco acordos e convênios internacionais foram assinados entre estados e municípios brasileiros e entes subnacionais (estados, regiões, comunidades, cantões, províncias) de países da Europa, Ásia, América Latina e outros. Entretanto, como a Constituição brasileira estabelece o princípio segundo o qual somente o Governo Federal possui poder e voz em matéria de política externa, estes compromissos firmados por componentes federados brasileiros no exterior podem ser considerados apenas "informais". Em alguns casos, os atos são destituídos de conotações normativas; em outros, geram expectativas de Direito sem nenhum amparo no ordenamento jurídico nacional. Com o objetivo de dar base institucional, potencializar e dar maior capilaridade às ações internacionais do país, abrindo novos nichos de oportunidade para o desenvolvimento econômico e social da federação, apresentamos no Congresso Nacional a Proposta de Emenda à Constituição (PEC) 475/2005, a chamada "PEC da 
Paradiplomacia", que acrescenta parágrafo ao artigo 23 da Constituição para permitir que estados, Distrito Federal e municípios possam promover atos e celebrar acordos ou convênios com entes subnacionais estrangeiros (COSTA, 2016).

40 A paradiplomacia é considerada como uma das expressões de atuação internacional de governos subnacionais. Teve sua origem nos países industrializados do Norte e logo se espalhou para todo o mundo. No Brasil, a articulação dos governos Estaduais e locais datam dos anos oitenta, porém, com práticas mais habituais das atividades paradiplomáticas de cooperação e de promoção econômica comercial a partir da década de dois mil (RIBEIRO, 2009).

41 Sujeito de direito internacional é aquele "capaz de possuir direitos e deveres, possuindo também a capacidade de manter seus direitos por meio de reclamações internacionais ( ICJ,1949, p. 9).

\section{REFERÊNCIAS}

ALMEIDA, Lúcio Flávio de. Entre o local e o global: poder e política na atual fase de transnacionalização do capitalismo. In: DOWBOR, Ladislau; IANNI, Octavio; RESENDE, Paulo Edgar A. (org.). Desafios da globalização. Petrópolis, RJ: Vozes, 1998.

ARNAUD, André-Jean; DULCE, María José Fariñas. Introdução à análise dos sistemas jurídicos. Trad. Eduardo Pellew Wilson. Rio de Janeiro: Renovar, 2000.

ARTICLE L1115-1. Disponível em: <https://www.legifrance.gouv.fr/affichCodeArticle. do? cidTexte=LEGITEXT000006070633\&idArticle=LEGIARTI000006389099\&dateTexte $=\&$ categorieLien $=$ cid"categorieLien $=$ cid $>$. Acesso em: 7 set. 2016 .

BRASIL. Constituição da República Federativa dos Estados Unidos do Brasil de 1891. Rio de Janeiro, 1891. Disponível em: <http://www.planalto.gov.br/ccivil_03/Constituicao/ Constituicao91.htm>. Acesso em: 2 ago. 2016.

BRASIL. Constituição dos Estados Unidos do Brasil (de 10 de novembro de 1937).

Disponível em: <http://www.planalto.gov.br/ccivil_03/Constituicao/Constituicao37. htm>. Acesso em: 05 jun. 2016.

BRASIL. Constituição da República Federativa do Brasil de 1988. Brasília, 1988. Disponível em: <http://www.planalto.gov.br/ccivil_03/Constituicao/Constituicao.htm>. Acesso em: 05 jun. 2016.

BRASIL. Comissão de Constituição e Justiça e de Cidadania. Projeto de emenda à Constituição n. 475, de 2005. Acrescenta parágrafo ao art. 23 da Constituição Federal para permitir que Estados, Distrito Federal e Municípios possam promover atos e celebrar acordos ou convênios com entes subnacionais estrangeiros. 4 p. Disponível em: $<$ http://www.camara.gov.br/proposicoesWeb/prop_mostrarintegra?codteor=388392H YPERLINK "http://www.camara.gov.br/proposicoesWeb/prop_mostrarintegra?codteor $=388392 \&$ filename $=$ PRL+1+CCJC+\%3D\%3E+PEC+475/2005” \&HYPERLINK “http:// www.camara.gov.br/proposicoesWeb/prop_mostrarintegra? codteor=388392\&filena $\mathrm{me}=\mathrm{PRL}+1+\mathrm{CCJC}+\% 3 \mathrm{D} \% 3 \mathrm{E}+\mathrm{PEC}+475 / 2005$ "filename $=\mathrm{PRL}+1+\mathrm{CCJC}+\% 3 \mathrm{D} \% 3 \mathrm{E}+\mathrm{P}$ EC+475/2005>. Acesso em: 12 out. 2016. 
BRASIL. Constituição da República Federativa do Brasil. 51. ed. São Paulo: Saraiva, 2015.

BRITO, Vlademir Augusto Correia. Convenção-quadro Européia sobre a cooperação transfronteiriça entre as coletividades ou autoridades territoriais. Coimbra: Stvddia Ivridica, 2000.

BURSENS, Peter; MASSART-PIÉRARD, Françoise. Kingdom of Belgium. In: MICHELLMANN, Hans (ed.). Foreign relations in federal countries. Madrid: McgillQueen's University Press, 2009.

CAREAU, Dominique; BICHARA, Jahyir-Philippe. Direito internacional. Rio de Janeiro: Lumen Juris, 2015.

CEZÁRIO, Gustavo Lima. A atuação global municipal: dimensões e institucionalização. 2011. 212 p. Dissertação (Mestrado em Relações Internacionais) - Universidade de Brasília (UnB), Brasília, 2011.

COSTITUZIONE DELLA REPUBBLICA ITALIANA (in GU 7 dicembre 1947). Disponível em: <http://www.edscuola.it/archivio/norme/leggi/costituzione.html>. Acesso em: 7 set. 2016.

DAL RI, Arno (org.). Às sombras da soberania: a condição jurídica de Estados Federados e governos infraestatais no Direito Internacional. Florianópolis: Fundação Boatex, 2010.

DAL RI JÚNIOR, Arno. História do direito internacional: comércio e moeda, cidadania e nacionalidade. Florianópolis: Fundação Boiteux, 2004.

DAL RI JÚNIOR, Arno; VELOSO, Paulo Potiara de Alcântara; LIMA, Lucas Carlos (org.). A formação da ciência do direito internacional. Ijuí: Ed. Unijuí, 2014.

DALLARI, Dalmo de Abreu. Elementos de Teoria Geral do Estado. 19. ed. São Paulo: Saraiva, 1995.

DALLARI. Elementos de Teoria Geral do Estado. 25. ed. São Paulo: Saraiva, 2005.

DING, Nguyen Quoc; DALLIER, Patrick; PELLET, Alain. Direito internacional público. Trad. Vítor Marques Coelho. 2. ed. Lisboa: Fundação Calouste Gulbenkian, 2003.

DOWBOR, Ladislau; IANNI, Octavio; RESENDE, Paulo Edgar A. (org.). Desafios da globalização. Petrópolis, RJ: Vozes, 1998.

DUCHACEK, Ivo D. Perforated sovereignties: towards a typology of new actors in international relations. New York: Oxford University Press, 1990.

FARIA, José Eduardo (org.). A noção de paradigma na ciência do direito: notas para uma crítica ao idealismo jurídico. Brasília: Unb, 1988.

FERREIRA, Wolfran Junqueira. O Município à luz da Constituição Federal de 1988. São Paulo: Edipro, 1993. 
FREITAS JÚNIOR, Antônio Rodrigues de. Globalização, Mercosul e crise do EstadoNação: perspectivas para o direito em uma sociedade em mudança. São Paulo: LTR, 1997.

GROSSI, Paolo. Mitologias jurídicas da modernidade. Trad. Arno Dal Ri Júnior. 2. ed. Florianópolis: Fundação Boiteux, 2007.

GROSSI, Paolo. O direito entre o poder e o ordenamento. Trad. de Arno Dal Ri Júnior. Belo Horizonte: Del Rey, 2010.

GROSSI, Paolo. Primeira lição sobre direito. Tradução de Ricardo Marcelo Fonseca. Rio de Janeiro: Forense, 2011.

GROSSI, Paolo. A ordem jurídica medieval. Trad. de Denise Rossato Agostinetti. São Paulo: Martins Fontes, 2014.

HRBEK, Rudolf. Federal Republic of Germany. In: MICHELLMANN, Hans (ed.). Foreign Relations in Federal Countries. Madrid: Mcgill-Queen's University Press, 2009.

ICJ. Reparation for injuries suffered in the service of the United Nations - advisory opinion of april 11th, 1949. Haia: International Court of Justice, 1949.

JOS, Emmanuel. Collectivités territoriales non-étatiques et système juridique internacional dans le contexte de la mondialisation. In: SOCIÉTÉ FRANÇAISE POUR LE DROIT INTERNATIONAL. Journée d'études Les collectivités territoriales non-étatiques dans le système juriddique interncalional. Paris: Pedone, 2002.

LA CONSTITUCION BELGE. Disponível em: <http://www.senate.be/doc/const_ fr.html>. Acesso em: 6 set. 2016.

LEJEUNE, Yves. Belgium. In: MICHELMANN, Hans J.; SOLDATOS, Manayotis (ed.). Federalism and internacional relations: the role of subnational units. New York: Oxford University Press, 1990. p. 142-175.

LES VILLES et le Droit Internacional. Université Paris Ouest Naterre La Défense Bâtiment F Amphi D. Vendredi, jun. 2006. Disponível em: <https://www.google.com.br/searc $\mathrm{h} ? \mathrm{q}=$ Les+Villes+et+le+Droit+Internacional\&ie $=$ utf-8\&oe=utf-8\&gws_rd=cr\&ei= ziyVV6eVIcKHwgTOjqnYBA>. Acesso em: 24 jul. 2016.

LOSANO, Mário G. Os grandes sistemas jurídicos: introdução aos sistemas jurídicos europeus e extra-europeus. Trad. Marcelo Varejão. São Paulo: Martins Fontes, 2007.

KUHN, Thomas. A estrutura das revoluções científicas. Trad. Beatriz Vianna Boeira e Nelson Boeira. 5. ed. São Paulo: Perspectiva, 2000.

MARIA, Luis. La política internacional subnacional em América Latina. Buenos Aires: Libros del Zorzal, 2010.

NOGUEIRA, Ataliba et al. Teoria do Município. Revista dos Tribunais - Doutrinas Essenciais, São Paulo, v. III, p. 456- 487, 2011. 
PERGOLA, Antonio La et al. Regionalismo, federalismo e poder externo do Estado: o caso italiano e o direito comparado. Revista dos Tribunais - Doutrinas Essenciais, São Paulo, v. I, p. 645-688, 2012.

REVERBEL, Carlos Eduardo Dieder. Federalismo, descentralização e subsidiariedade. In: SOUZA JUNIOR, Cesar Saldanha; AVILA, Marta Marques (org.). Direito do Estado: estudos sobre federalismo. Porto Alegre: Dora Luzzatto, 2007. Cap. 1. p. 39-64.

RIBEIRO, Jomara de Carvalho. A questão da personalidade jurídica internacional das empresas multinacionais. In: V Encontro Internacional do Conpedi em Montevidéu, set. 2016. Disponível em: <http://www.conpedi.org.br/manaus/arquivos/anais/ bh/jomara_ de_carvalho_ribeiro.pdf $>$. Acesso em: 17 ago. 2016.

RIBEIRO, Maria Clotilde Meirelles. Globalização e novos atores: a paradiplomacia das cidades brasileiras. Salvador: EDUFA, 2009.

ROBERTSON, Roland. Globalização: teoria social e cultura global. Petrópolis, RJ: Vozes, 1999.

RODRIGUES, Gilberto Marcos Antonio. O que são relações internacionais? São Paulo: Brasiliense, 1994.

RODRIGUES, Gilberto Marcos Antonio. A política externa federativa. In: Política Externa - Network, v. 7, n. 3. Rio de Janeiro: Universidade Cândido Mendes, set./dez. 1998.

ROMANO, Santi. Corso di Diritto Internazionale. Padova: Dott. Antonio Milani, 1939.

ROMANO, Santi. Princípios de direito constitucional geral. Trad. Maria Helena Diniz. São Paulo: Revista dos Tribunais, 1977.

ROMANO, Santi. O ordenamento jurídico. Trad. Arno Dal Ri Júnior. Florianópolis: Fundação Boiteux, 2008.

SANTA CATARINA nas relações internacionais: desafios da Assembleia Legislativa do Estado de Santa Catarina no cenário internacional. In: DAL RI, Arno (org.). Às sombras da soberania: a condição jurídica de Estados Federados e governos infraestatais no Direito Internacional. Florianópolis: Fundação Boatex, 2010.

SAULE JÚNIOR, Nelson et al. Retratos sobre a atuação da sociedade civil pelo direito à cidade: diálogo entre Brasil e França. In: UZZO, Karina et al. (org.). Panorama de l'action de la société civilr pour lê droit à la Ville: ialogue entrele Brésil el la France. São Paulo: Instituto Polis; Paris: AITEC, 2006.

SEITENFUS, Ricardo Antônio Silva. Manual das organizações internacionais. 2. ed. Porto Alegre: Livraria do Advogado, 2000. 367 p.

SILVA, José Afonso da. Curso de direito constitucional positivo. 14. ed. São Paulo: Malheiros, 1992. 
TEXTE INTÉGRAL de la Constitution du 4 octobre 1958 en vigueur. Disponível em: <http://www.conseil-constitutionnel.fr/conseil-constitutionnel/francais/la-constitution/ la-constitution-du-4-octobre-1958/texte-integral-de-la-constitution-du-4-octobre-1958en-vigueur.5074.html>. Acesso em: 6 set. 2016.

TOUSCOZ, Jean. Direito internacional. Trad. de Nuno Cana Mendes. Portugal: Publicações Europa-América Ltda., 1993.

VARELA, Marcelo D. Direito internacional público. 3. ed. São Paulo: Saraiva, 2011.

VIGEVANI, Tullo et al. (org.). A dimensão subnacional e as relações internacionais. São Paulo: Educ; Fundação Editora da UNESP; EDUSC. 2004.

Submetido: $05 / 02 / 2020$

Aceito: $10 / 02 / 2020$ 


\title{
OS GOVERNOS NÃO CENTRAIS: COMPARTILHAMENTO DE COMPETÊNCIAS NA DIMENSÃO SUBNACIONAL DOS ESTADOS
}

\begin{abstract}
Resumo
O artigo problematiza sobre o compartilhamento de competências dos denominados governos não centrais, situados na dimensão subnacional e local (Estados federados, municípios e comunidades territoriais não estatais). Os governos não centrais, consideradas as especificidades de sua natureza jurídica e atividades desenvolvidas na atualidade e cena internacional, também podem ser classificados como sujeitos emergentes da sociedade internacional contemporânea. $\mathrm{O}$ desenvolvimento temático se concentra na abordagem preliminar do compartilhamento de competências dos Estados federados e comunidades estatais nos ordenamentos europeus, seguida da inserção dos municípios brasileiros no assunto. A conclusão se dirige em apontar que o compartilhamento de competências entre Estado e entidades territoriais de caráter público, no equilíbrio interno dos Estados, se fortalece cada vez mais no contexto da atual conjuntura política e econômica que liga o global ao local e vice-versa, provocadora de uma significativa flexibilização da soberania Estatal centralizada, em tempos de grandes mudanças de paradigmas. Trata-se de pesquisa bibliográfica, pautada pela utilização do método dedutivo.
\end{abstract}

Palavras-chave: Governos não Centrais. Competências. Dimensão subnacional dos Estados. 


\title{
NON-CENTRAL GOVERNMENTS: SHARING COMPETENCIES IN THE SUBNATIONAL DIMENSION OF STATES
}

\begin{abstract}
The article discusses the sharing of competences of so-called non-central governments, located in the subnational and local dimension (federated states, municipalities and nonstate territorial communities). Non-central governments, considering the specificities of their legal nature and activities developed today and on the international scene, can also be classified as emerging subjects of contemporary international society. The matter focuses on the preliminary approach to the sharing of competences of federal states and state communities in European systems, followed by the insertion of Brazilian municipalities on the subject. The conclusion is directed at pointing out that the sharing of competences between the State and territorial entities of a public nature, in the internal balance of the States, is increasingly strengthened in the context of the current political and economic conjuncture that links the global to the local and vice versa, provoking a significant flexibility of centralized State sovereignty, in times of great paradigm changes. This is a bibliographic research, based on the use of the deductive method.
\end{abstract}

Keywords: Non-central governments. Jurisdiction. Subnational dimension of States. 